\title{
Preliminary Study on Factors that Enhanced the Production of Uricase by Aspergillus Flavus
}

\author{
M. Siti Hatijah and W. R. Wan Ruhayu
}

\begin{abstract}
Urate oxidase or uricase is an enzyme that catalyses the oxidation of uric acid to allantoin and plays important rule in purine metabolism. The first important application discovered for uricase was in clinical biochemistry as diagnosis reagent for measurement of uric acid in blood. The precipitation of uric acid can leading to gout symptom. The main purpose of this research is to optimize the culture condition for maximum uricase production by Aspergillus flavus. The parameters studied were $\mathrm{pH}$ (ranged $\mathrm{pH} 4$ to $\mathrm{pH8}$ ), the sucrose concentration $(10 \mathrm{~g} / \mathrm{l}$ to $50 \mathrm{~g} / \mathrm{l})$ and the agitation rate (100 to $300 \mathrm{rpm})$. The Aspergillus flavus were inoculated in yeast extract with sucrose and incubated for 24 hours at $200 \mathrm{rpm}$ and $30^{\circ} \mathrm{C}$. The maximum enzyme activity obtained from the experiment is $0.03974 \mathrm{U} / \mathrm{ml}$ at $\mathrm{pH} 6,200 \mathrm{rpm}$ and $30 \mathrm{~g} / \mathrm{l}$ sucrose concentration.
\end{abstract}

Index Terms-Aspergillus flavus, gout, uric acid, uricase.

\section{INTRODUCTION}

In the past few decades, gout has markedly increased in incidence and prevalence in Malaysia and elsewhere. Gout patients nowadays are more clinically complex than in past due to combinations of advanced age and drug-drug interactions [1]. Fortunately, recent research on novel advances in treatments highlights how gout can be better managed with cost effective and well established therapies using therapeutic enzyme called urate oxidase.

Urate oxidase (uricase) is an enzyme found in liver peroxisomes of most mammalian species, converts uric acid to a more soluble and easily excreted compound, i.e., allantoin [2]. Although this enzyme is widely present in most vertebrates, it was found absent in human [3]. When the level of uric acid increases in blood over than the normal value it can cause renal failure and may contribute to a group of diseases such as gout, leukimia, toxemia of pregnancy, severe renal impairment and idiopathic calcium urate nephrolithiasis [4]. The first application of uricase in clinical biochemistry is as diagnostic reagents for measurement of uric acid in blood and other biological fluids [5]. Purified uricase from Asperfillus flavus has been found effective in the treatment of hyperuricemia and gout [6].

Manuscript received February 8, 2013; revised May 20, 2013. This work was supported by University Malaysia Pahang Internal Grant (RDU120370).

M. Siti Hatijah and W. R. Wan Ruhayu are with the Faculty of Chemical Engineering \& Natural Resources, Universiti Malaysia Pahang, Lebuhraya Tun Razak, 26300 Gambang, Kuantan, Pahang, Malaysia (e-mail: hatijah@ump.edu.my).

\section{METHODOLOGY}

\section{A. Culture Condition of Fungi}

The Aspergillus flavus strain use in this research was obtained from Malaysian Agricultural Research and Development Institute (MARDI). The cultures are maintaining on potato dextrose agar (PDA) and stored at 5 ${ }^{\circ} \mathrm{C}$.

\section{B. Inoculums Preparation}

Cultures were transferred in to $250 \mathrm{ml}$ conical flasks containing $100 \mathrm{ml}$ aliquots which are $1 \%$ of yeast extract, $10 \%$ sucrose and distilled water. It was incubated in an incubator shaker operating $200 \mathrm{rpm}$ at $30{ }^{\circ} \mathrm{C}$ for 24 hours. At the end of incubation, $1.5 \mathrm{ml}$ of the culture was monitored at $540 \mathrm{~nm}$ using spectrophotometer. The optical density was set at 0.60 .

\section{Fermentation Medium}

Inoculum with $10 \mathrm{ml}$ culture was transferred into $250 \mathrm{ml}$ conical flask containing $90 \mathrm{ml}$ of medium, and was used for the study of the condition of the fermentation with following medium used: $20 \mathrm{~g} / 1$ peptone, $30 \mathrm{~g} / \mathrm{l}$ sucrose, $1 \mathrm{~g} / 1 \mathrm{KH}_{2} \mathrm{PO}_{4}$, $0.5 \mathrm{~g} / \mathrm{l} \mathrm{MgSO}_{4} .7 \mathrm{H}_{2} \mathrm{O}$, and $0.3 \mathrm{~g} / \mathrm{l}$ uric acid. The culture condition experiments were performed in 12 samples. During the fermentation, a sample of the culture was withdrawn at 4 hours intervals for 48 hours. Then, the entire cells were collected by centrifugation at $8000 \mathrm{rpm}$ for 2 minutes. Then, the supernatants were used for enzyme analysis and the cell was dried at $60{ }^{\circ} \mathrm{C}$ for overnight.

\section{Effect of $p H$}

The effect of $\mathrm{pH}$ on uricase production was examined using the $250 \mathrm{ml}$ conical flask containing $100 \mathrm{ml}$ of medium and incubated as described above. To determine the optimal $\mathrm{pH}$ for uricaseproduction, the inoculum were cultured in the $\mathrm{pH}$ media, of which the $\mathrm{pH}$ adjusted to 4.0, 5.0, 6.0, 7.0, 8.0 and 9.0 .

\section{E. Effect of Sucrose Concentration}

The effect of sucrose concentration on uricase production was examined using the $250 \mathrm{ml}$ conical flask containing 100 $\mathrm{ml}$ of medium and incubated as described above. To determine the optimal sucrose concentration for uricase production, the inoculums were cultured in the media, of which the sucrose concentration adjusted to $10,20,30,40$ and $50 \mathrm{~g} / \mathrm{l}$.

\section{F. Effect of Agitation Rate}

The effect of agitation rate on uricase production was examined using the $250 \mathrm{ml}$ conical flask containing $100 \mathrm{ml}$ of 
medium and incubated as described above. To determine the optimal agitation rate for uricase production, the inoculum were cultured in the media, of which the agitation rate adjusted to $100,150,200,250$ and $300 \mathrm{rpm}$.

\section{G. Enzyme Assay}

The principle of enzyme measurement was as follow: uricase could catalyze the oxidation of uric acis into allation and $\mathrm{H} 2 \mathrm{O} 2$ which was them measured by using a reaction system containing 4-aminoantipyrine, phenol and peroxidase as chromogen. In practical analysis, $0.1 \mathrm{ml}$ enzyme solution was incubated with the mixture of $0.6 \mathrm{ml}$ sodium borate buffer $(\mathrm{pH} 8.5,0.1 \mathrm{M}$ ) containing $2 \mathrm{mM}$ uric acid, $0.15 \mathrm{ml}$ 4-aminoantipyrine $(30 \mathrm{mM}), 0.1 \mathrm{ml}$ phenol $(1.5 \%), 0.05 \mathrm{ml}$ peroxidase $(15 \mathrm{U} / \mathrm{ml})$ at $37{ }^{\circ} \mathrm{C}$ for $20 \mathrm{~min}$. The reaction was stopped by addition of $0.1 \mathrm{ml}$ ethanol. Then, the sample was followed modified DNS method to determine glucose concentration at $540 \mathrm{~nm}$ was read against the blank by a spectrometer. One unit of enzyme was defined as the amount of enzyme that produces $1.0 \mathrm{mmol}$ of $\mathrm{H}_{2} \mathrm{O}_{2}$ per minute under the standard assay conditions.

\section{RESUlTS AND DisCUSSION}

\section{A. Effect of $p H$}

The result in Fig. 1 shows pH 6 of fermentation medium give the highest enzyme activity of the extracellular product with $0.03974 \mathrm{U} / \mathrm{ml}$. For $\mathrm{pH} 4$ and $\mathrm{pH}$ 5, enzyme activity obtained was $0.02662 \mathrm{U} / \mathrm{ml}$ and $0.02932 \mathrm{U} / \mathrm{ml}$ while for $\mathrm{pH} 7$ and $\mathrm{pH} 8$ were $0.03549 \mathrm{U} / \mathrm{ml}$ and $0.03433 \mathrm{U} / \mathrm{ml}$. Acidic fermentation medium give higher production medium as compared to more basic fermentation medium. The result was coincided with those of Tohamy and Shindia [7] and Yazdi et al. [5] who found that $\mathrm{pH} 6.0$ was optimum $\mathrm{pH}$ medium for uricase production from Aspergillus flavus and Mucor hiemalis, respectively. However, this result is in disagreement by Ammar et al. [8] which reported optimum $\mathrm{pH}$ for uricase by Aspergillus flavus was 9.2. Besides that, Tohamy and Shindia [7] reported that species Aspergillus terreus produced maximum uricase production at $\mathrm{pH} 6$ and $30{ }^{\circ} \mathrm{C}$.

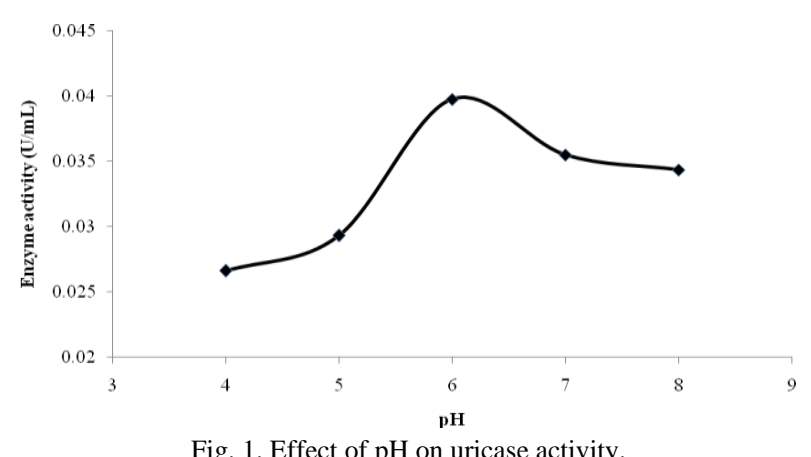

The optimal $\mathrm{pH}$ of most enzymes is from $6-8$, but there may be exceptions. Most extremely acidic or basic environments cause the enzyme to denature, unravelling the protein structure [9]. Once enzymes are denatured, they are rendered inactive. This is important to biology because if there are too many acidic environments in the body certain functions may work inappropriately because of unusual $\mathrm{pH}$ levels. If the medium contains a lot of hydrogen ions $(\mathrm{H}+)$, then the medium will be acidic.

Strain Bacillus thermocatenulatus was proved by Lotfy [10] give highest uricase production of $1.25 \mathrm{U} / \mathrm{ml}$ at $\mathrm{pH} 7$. The highest dried cell weight (1.85 g) for uricase production was also observed at $\mathrm{pH}$ 6. Anderson and Vijayakumar [11] found $\mathrm{pH} 8.5$ give highest production of uricase using Pseudomonas aeruginosa while Zhou et al. [3] found that $\mathrm{pH}$ 7.5 was optimum $\mathrm{pH}$ for Microbacterium for production of uricase.

\section{B. Effect of Sucrose Concentration}

The fermentation medium was prepared at different sucrose concentration $(10,20,30,40$ and $50 \mathrm{~g} / \mathrm{l})$ at $\mathrm{pH} 6$ and $200 \mathrm{rpm}$. Study on effect of sucrose concentration on uricase production showed that the enzyme productivity decreased in the following order: $30>40>50>20$ and $10 \mathrm{~g} / \mathrm{l}$. Fig. 2 shows that at $30 \mathrm{~g} / \mathrm{l}$ sucrose concentration, the highest uricase activity and dried cell weight were detected at $0.03974 \mathrm{U} / \mathrm{ml}$ and $1.85 \mathrm{~g} / \mathrm{l}$, respectively. For $40 \mathrm{~g} / \mathrm{L}$ concentration, enzyme activity obtained $0.03395 \mathrm{U} / \mathrm{ml}$ and $1.342 \mathrm{~g}$ of dried cell weight while for concentration $50 \mathrm{~g} / \mathrm{l}$ and $20 \mathrm{~g} / \mathrm{l}$ give the enzyme activity $0.02315 \mathrm{U} / \mathrm{ml}$ and $0.02276 \mathrm{U} / \mathrm{ml}$. However, dried cell weight of $20 \mathrm{~g} / \mathrm{l}$ was higher with $0.982 \mathrm{~g}$ than $50 \mathrm{~g} / \mathrm{l}$ with $0.895 \mathrm{~g}$ of dried cell weight. For $10 \mathrm{~g} / \mathrm{l}$, it gave the lowest enzyme activity with $0.01312 \mathrm{U} / \mathrm{ml}$ and lowest dried cell weight with $0.873 \mathrm{~g}$.

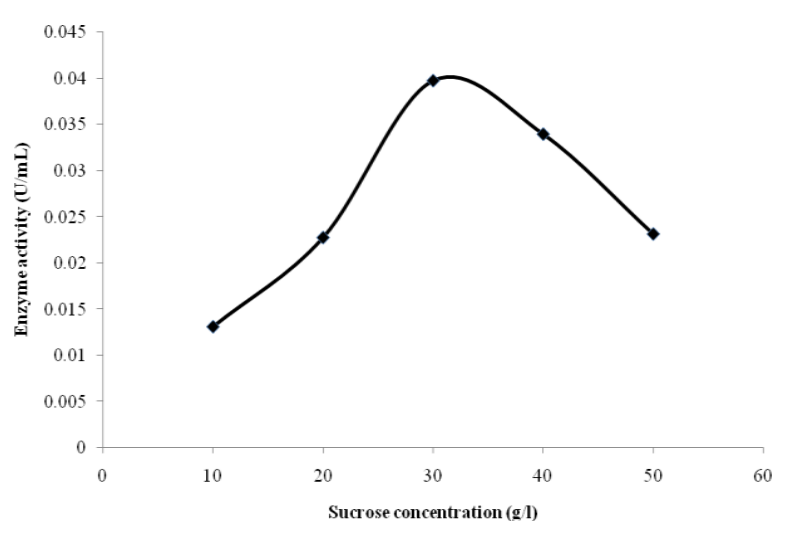

Fig. 2. Effect of sucrose concentration on uricase activity.

Substrate concentration affects the rate of enzymatic reactions. At lower substrate concentrations, the reaction rate is strictly proportional to the substrate concentration. However, once the substrate molecule concentrations increase beyond a certain level, there are no more binding sites available for them. This is called saturation, when enzymes catalyze as fast as they can, and reaction rate reaches its maximum potential. Without substrate, enzymes cannot function, and without the appropriate amount of substrate, the velocity of the reactions would take place very slowly [12]. When this saturation point is reached, then adding extra substrate will make no difference. The reaction will not speed up, no matter how much additional substrate is added. The graph of the reaction rate will plateau.

\section{Effect of Agitation Rate}

The experiment was designed determine agitation rate that give highest production of uricase. The agitation uses were 
100, 150, 200, 250 and $300 \mathrm{rpm}$. From the result, the production of uricase was highest at agitation rate $200 \mathrm{rpm}$ with $0.03974 \mathrm{U} / \mathrm{ml}$. After that, agitation rate of $250 \mathrm{rpm}$ gave the second highest enzyme activity with $0.03781 \mathrm{U} / \mathrm{ml}$ and followed by agitation rate at $300 \mathrm{rpm}$ with $0.02701 \mathrm{U} / \mathrm{ml}$. At $150 \mathrm{rpm}$, the enzyme activity obtained was $0.02623 \mathrm{U} / \mathrm{ml}$ and $100 \mathrm{rpm}$ gave the lowest enzyme activity with $0.02122 \mathrm{U} / \mathrm{ml}$. Some agitation rate increases the hydrolysis rate and yield, but excessive mixing can deactivate the enzyme and reduce the conversion yield [13], [14]. The deactivation effect has been attributed to shear force generated by the mixer and the entrapment of air bubbles into the medium at the air-liquid surface. In fact, the shear deactivation effect is a deterring factor in applying a more intensive agitation. However, a more properly designed and more intensive mixing regime should facilitate a better mass transfer inside the reactor, reducing a potentially high local product concentration surrounding the enzyme and active sites [15].

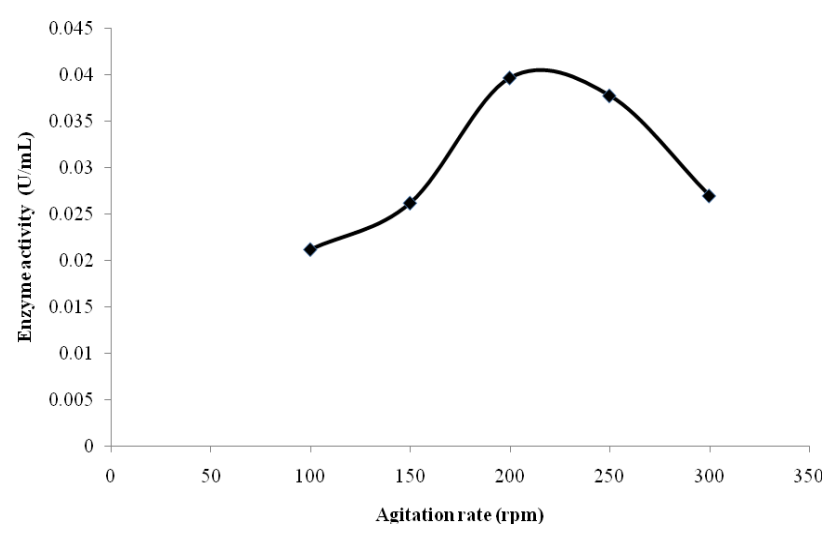

Fig. 3. Effect of agitation rate on uricase activity.

\section{CONCLUSION}

As conclusion, the optimum parameters for uricase production had been determined. The maximum enzyme activity obtained from the experiment is $0.03974 \mathrm{U} / \mathrm{ml}$ with dried cell weight $1.85 \mathrm{~g}$ at $\mathrm{pH}$ 6, $200 \mathrm{rpm}$ and $30 \mathrm{~g} / \mathrm{l}$ sucrose concentration. Further study on the optimization study using statistical method will carried out later to validate the results from this preliminary studies.

\section{ACKNOWLEDGMENT}

This research was supported by University Research Grant (RDU 120370) by Universiti Malaysia Pahang, Malaysia.

\section{REFERENCES}

[1] R. Terkeltaub, "Novel therapies for treatment of gout and hyperuricemia," Arthritis Research \& Therapy, vol. 11, pp. 236, 2009

[2] J. Li, Z. Chen, L. Hou, H. Fan, S. Weng, J. Ren, B. Li, and W. Chen, "High-level expression, purification, and characterization of non-tagged Aspergillus flavus urate oxidase in Escherichia coli," Protein Expression and Purification, vol. 49, pp. 55-59, 2006.

[3] X. L. Zhou, X. H. Ma, G. Q. Sun, X. Li, and K. P. Guo, "Isolation of a thermostable uricase-producing bacterium and study on its enzyme production conditions," Process Biochemistry, vol. 40, pp. 3749-3753, 2005.

[4] W. N. Kelly and T. D. Pellela, Gout and Other Disordes of Purine Metabolism. Harrison'S Principles of Internal Medicine, New York: McGraw Hill, pp. 1623-32, 1987.

[5] M. T. Yazdi, G. Zarrini, E. Mohit, M. A. Faramarzi, N. Setayesh, N. Sedighi, and F. A. Mohseni, "Mucor Hermalis: a new source for uricase production," World Journal of Microbiology \& Biotechnology, vol. 22, pp. 325-330, 2006.

[6] J. S. Bomalaski and M. A. Clark, "Serum uric acid-lowering therapies: where are we in management of hyperuricemia and the potential role of uricase," Current Rheumatology Reports, vol. 6, pp. 240-247, 2004.

[7] E. Y. Tohamy and A. A. Shindia, "Partial purification and some properties of uricase produced by strain of Aspergillus terreus," Egyptian Journal of Microbiology, vol. 36, pp. 77-87, 2001.

[8] M. S. Ammar, S. H. Elwan, and E. M. El-Desouky, "Purification and some properties of uricase from Aspergillus flavus S-97," Egypt $J$ Microbiol, vol. 23, pp. 83, 1988

[9] C. Campbell, N. Neil, and R. Reece, Biology, $6^{\text {th }}$ ed., California: Benjamin Cummings Publishing, pp. 300-340, 2002.

[10] W. A. Lotfy, "Production of a Thermostable Uricase by a Novel Bacillus Thermocatenulatus Strain," Bioresource Technology, pp. 699-702, 2008.

[11] A. Anderson and S. Vijayakumar, "Purification and Optimization of Uricase Enzyme Produced by Pseudomonas aeruginase," Journal of Experimental Sciences, pp. 5-8, 2011.

[12] D. U. Silverthon, Human Physiology: An Integrated Approach, Addison- Wesley Publishing, 2004, pp. 415-450.

[13] H. Ingesson, G. Zacchi, B. Yang, A. R. Esteghlalian, and J. N. Saddler, "The effect of shaking regime on the rate and extent of enzymatic hydrolysis of cellulose," Journal Biotechnology, vol. 88, pp. 177-182, 2001

[14] J. D. Wright, "Ethanol from biomass by enzymatic hydrolysis," Chemical Engineering Prog, vol. 89, pp. 62-74, 1988.

[15] S. I. Musatto, G. Dragone, M. Fernandes, A. M. F. Milagres, and I. C. Roberto, "The effect of agitation speed, enzyme loading and substrate concentration on enzymatic hydrolysis of cellulose from brewer's spent grain," Cellulose, vol. 15, pp. 711-721, 2008.

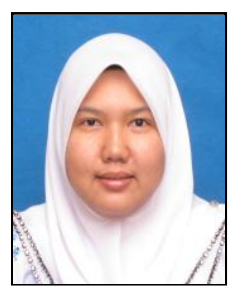

M. Siti Hatijah is a member of Institutions of Engineer Malaysia (IEM) and Institution of Chemical Engineers (IChemE). She graduated with bachelor of engineering (biochemical \& biotechnology) from International Islamic University Malaysia (IIUM) in 2006. She received her master of science (MSc) in chemical engineering from Universiti Sains Malaysia (USM) in 2010.

She currently served as a lecturer at Faculty of Chemical Engineering \& Natural Resources, Universiti Malaysia Pahang (UMP).The author's research interests are mainly focused in bioprocess engineering, enzyme technology and biochemical engineering. Her current active research is the production of thermostable uricase from microbial sources. 